Pengembangan Bahan Ajar.... (Fida Lestari, Asep Sukenda Egok, Riduan Febriandi)

\title{
PENGEMBANGAN BAHAN AJAR MATEMATIKA BERBASIS PROBLEM BASED LEARNING PADA SISWA KELAS V SD
}

\author{
Oleh: Fida Lestari ${ }^{1}$ Asep Sukenda Egok ${ }^{2}$ Riduan Febriandi $^{3}$ \\ Email : fidalestari98@gmail.com ${ }^{1}$ a sep.egok91@gmail.com ${ }^{2}$ \\ riduanfebriandi9@gmail.com ${ }^{3}$ \\ (PGSD STKIP-PGRI Lubuklinggau)
}

\begin{abstract}
Abstrak
Penelitian ini bertujuan untuk mengembangkan sebuah produk berupa bahan ajar Mathematic berbasis Problem Based Learning pada siswa kelas V SD Negeri 37 Lubuklinggau sesuai dengan kurikulum 2013 serta untuk menghasilkan bahan ajar yang valid dan praktis untuk digunakan dalam belajar. Penelitian ini merupakan penelitian pengembangan dengan model pengembangan diadaptasi dari model Four-D. Berdasarkan hasil analisis penilaian oleh ketiga ahli yaitu: ahli bahasa, ahli materi, dan ahli media menunjukkan bahwa bahan ajar materi statistika berbasis problem based learning memenuhi kriteria valid dengan ratarata skor 0,76. Sedangkan hasil analisis penilaian lembar kepraktisan guru dan siswa yang terdiri dari 9 orang diperoleh bahwa bahan ajar materi statistika berbasis problem based learning memenuhi kriteria praktis dengan rata-rata skor 95\%, sehingga dapat disimpulkan bahwa bahan ajar materi statistika berbasis Problem Based Learning memenuhi kriteria valid, praktis dan bisa digunakan dalam pembelajaran.
\end{abstract}

Kata Kunci : Pengembangan, Bahan Ajar Matematika, Problem Based Learning

\section{DEVELOPMENT OF MATH MATHEMATICS MATERIALS BASED ON PROBLEM BASED LEARNING ON CLASSES V SD}

\begin{abstract}
This study aims to develop teaching materials based on Mathematics Based Problem-Based Learning in fifth grade students of SD 37 Lubuklinggau in accordance with the 2013 curriculum and to produce valid and practical teaching materials for use in learning. This research is a development study with a development model adapted from the Four-D model. Based on the results of the analysis Based on the experts, namely: linguists, material experts, and media experts determine statistical teaching materials based on problem-based learning criteria meet the criteria with an average score of 0.76. Based on the analysis of teacher and student worksheets consisting of 9 people obtained from problembased learning based statistical teaching materials meet the requirements with an average score of 95\%, so that learning materials can be improved based on statistical problems Problem Based Learning requires valid, practical criteria and can be used in learning.
\end{abstract}

Keywords: Development, Mathematic Teaching Materials, Problem Based Learning 


\section{A. PENDAHULUAN}

Pendidikan adalah suatu usaha yang dilakukan untuk mengembangkan kemampuan dan kepribadian individu melalui proses atau kegiatan tertentu (pengajaran, bimbingan atau latihan) serta interaksi individu dengan lingkungannya untuk mencapai manusia seutuhnya (Arifin, 2012:39). Oleh karena itu, pendidikan merupakan suatu hal yang sangat penting dalam meningkatkan sumber daya manusia. Guru adalah salah satu komponen yang sangat penting dalam pelaksanaan pendidikan karena guru bertatap langsung dengan peserta didik dalam proses pembelajaran yang di dalam proses kegiatannya terjadi pentransferan ilmu pengetahuan serta penanaman nilai-nilai moral melalui bimbingan dari seorang pendidik.

Febriandin, 2020:30 berpendapat bahwa belajar adalah sebuah proses yang dilakukan untuk mendapatkan suatu ilmu, baik ilmu yang sudah ada, ilmu yang baru maupun pengembangan suatu ilmu dalam mencapai tujuan hidup yang lebih baik. Sunhaji (2014:32) Proses pembelajaran suatu usaha untuk membuat siswa belajar, sehingga situasi tersebut merupakan peristiwa belajar (even of learning) yaitu usaha untuk terjadinya perubahan tingkah laku dari siswa, Perubahan tingkah laku dapat terjadi karena adanya interaksi antara siswa dengan lingkungannya.

Selama ini proses pembelajaran khususnya pembelajaran matematika yang dilaksanakan oleh guru masih menggunakan pembelajaran yang lebih menekankan pada hafalan dan mencari satu jawaban yang benar untuk soal-soal yang diberikan, proses pemikiran tingkat tinggi dan kreatifitas kurang dilatih. Sehingga siswa kurang termotivasi untuk belajar Matematika.

Oleh karena itu, sebagai seorang guru dituntut harus mampu mengajar dengan baik dan menarik serta mampu menciptakan proses pembelajaran yang bervariasi misalnya kreatif dalam memadukan model pembelajaran, menyesuaikan dengan keadaan peserta didik dan memilih bahan ajar yang tepat dalam pembeajaran Matematika. Oleh sebab itu, perlu adanya perbaikan dan peningkatan dalam pembelajaran Matematika seperti bahan ajar yang menarik dan inovatif agar siswa termotivasi dan tertarik untuk belajar Matematika. 
Hasanah (2012:151) mengemukakan bahwa sumber belajar merupakan informasi yang disajikan dan disimpan dalam berbagai bentuk media, yang dapat membantu siswa dalam belajar sebagai perwujudan dari kurikulum, bentuknya tidak terbatas apakah dalam bentuk cetakan, video, format perangkat lunak atau kombinasi dari berbagai format yang dapat digunakan oleh siswa ataupun guru. Proses pembelajaran dalam kurikulum 2013 harusnya berpusat pada peserta didik dan pendidik hanya sebagai fasilitator. Oleh karena itu, di dalam proses pembelajaran guru diharapkan tidak hanya menggunakan satu model, metode, media pebelajaran dan sumber belajar saja melainkan memakai model, metode, media pembelajaran dan sumber belajar yang inovatif dan menarik dengan tujuan agar bisa menumbuhkan semangat dan motivasi peserta didik agar lebih aktif dan kreatif.

Adapun permasalahan yang terjadi disalah satu Sekolah Dasar yaitu guru masih menerapkan pembelajaran yang konvensional, bahan pembelajaran yang digunakan masih sangat minim, seperti yang kita ketahui bahwa bahan ajar ini sudah menjadi penunjang atau alat bantu pendidik untuk mentransferkan materi dan memberikan soal-soal maupun tugas kepada peserta didik. Tetapi pada kenyataannya bahan ajar yang dipakai sulit dipahami peserta didik, kurang menarik dan peserta didik kurang mampu memahami maksud dari soal-soal yang terdapat di dalam bahan ajar tersebut, dari permasalahan tersebut mempengaruhi hasil belajar siswa kelas $\mathrm{V}$ yang belum maksimal.

Untuk mencapai proses pembelajaran yang maksimal pendidik diharapkan mampu menciptakan proses pembelajaran yang bisa memotivasi dan mengaktifkan peserta didik dalam proses pembelajaran. Sehingga dari permasalahan yang terjadi dapat memungkinkan saya sebagai peneliti mampu menghasilkan produk bahan ajar yang signifikan diharapkan oleh peserta didik untuk meningkatkan hasil afektif maupun kognitif peserta didik dalam proses pembelajaran, khususnya dalam pembelajaran matematika. Untuk memfasilitasi peningkatan hasil belajar matematika peserta didik perlu didukung oleh model pembelajaran yang tepat sehingga tujuan pembelajaran dapat tercapai sesuai dengan apa yang diharapkan. Menurut Sumartini (dalam Nurhidayati, dkk. 
2017:238) mengemukakan bahwa salah satu model pembelajaran yang dianggap dapat menfasilitasi kemampuan penalaran siswa adalah pembelajaran berbasis masalah (Problem Based Learning).

Berdasarkan uraian latar belakang di atas, perlu dilakukan pengembangan bahan ajar dengan menggunakan model pembelajaran Problem Based Learning agar bisa mengatasi permasalahan belajar peserta didik dan mampu mengembangkan kreatifitas dan keaktifan peserta didik pada pelajaran matematika yang sedang terjadi di Sekolah Dasar tersebut. Maka peneliti tertarik untuk melakukan penelitian yang berjudul "Pengembangan Bahan Ajar Matematika Berbasis Problem Based Learning pada Siswa Kelas V Sekolah Dasar".

\section{B. METODOLOGI PENELITIAN}

Peneliti mengembangkan bahan ajar dengan menggunakan metode penelitian Research and Development (R\&D). Kharisma \& Asman (2018:38) menyatakan bahwa penelitian pengembangan (Research and Development) merupakan penelitian yang bertujuan untuk menghasilkan produk dengan kualitas valid dan praktis ditinjau dari kemampuan pemecahan masalah dan prestasi belajar peserta didik. Penelitian ini menghasilkan produk berupa bahan ajar Mathematic dengan menggunakan model Problem Based Learning (PBL) tentang materi statistika. Adapun Desain dan pengembangan bahan ajar menggunakan model pengembangan 4-D berikut ini:

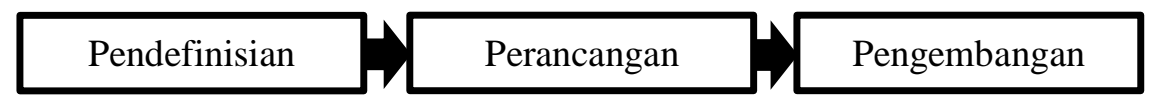

\section{Gambar 3.1 Model Pengembangan Bahan Ajar 4-D Modifikasi Thiagarajan \& Semmel dalam Trianto (2010:190)}

\section{Teknik Pengumpulan Data}

a. Wawancara

Mahmud (2011:173) menyatakan bahwa wawancara adalah teknik pengumpulan data dengan mengajukan pertanyaan kepada responden dan mencatat atau merekam jawaban-jawaban responden. Didukung oleh 
pendapat Sugiyono (2010:194) mengemukakan bahwa wawancara digunakan sebagai teknik pengumpulan data apabila peneliti ingin melakukan studi pendahuluan untuk menemukan permasalahan yang harus diteliti dan juga apabila peneliti ingin mengetahui hal-hal dari responden yang lebih mendalam dan jumlah respondennya sedikit/kecil.

b. Angket

Sugiyono (2015:199) mengemukakan bahwa Angket merupakan teknik pengumpulan data yang dilakukan dengan cara memberi seperangkat pertanyaan atau pernyataan tertulis kepada responden untuk dijawabnya. Langkah selanjutnya setelah memperoleh informasi dari responden yaitu cara untuk mengukur respon responden atau peserta didik terhadap bahan ajar Mathematic yang telah dibuat selanjutnya hasil angket yang berupa pertanyaan tersebut dianalisis dengan menggunakan skala Likert dan skala Guttman.

\section{Teknik Analisis Data}

Peneliti menggunakan analisis deskriptif kuantitatif untuk mengelola data dalam penelitian ini. Statistik deskriptif adalah statistik yang digunakan untuk mengidentifikasi data dan mendeskripsikan data yang telah terkumpul. Sesuai dengan pendapat Sugiyono (2014:29) Statistik deskriptif berfungsi untuk mendeskripsikan atau memberi gambaran terhadap obyek yang diteliti melalui data sampel atau populasi sebagaimana adanya, tanpa melakukan analisis dan membuat kesimpulan yang berlaku untuk umum.

\section{a. Uji Kevalidan Bahan Ajar}

Arikunto (2010:211) mengemukakan bahwa validitas adalah suatu ukuran yang menunjukkan tingkat-tingkat kevalidan atau kesahihan sesuatu instrumen, sebuah instrumen dikatakn valid apabila mampu mengukur apa yang diinginkan apabila dapat mengungkapkan data dari variabel yang diteliti secara tepat. Uji validitas pada tahap ini adalah validitas teoritik yaitu validasi yang dilakukan oleh para ahli di bidangnya. Karakteristik yang akan divalidasi yaitu: bahasa, materi, dan media, validator tersebut menganalisis 
bahan ajar yang dirancang dan memberikan saran serta masukan pada rancangan bahan ajar. Lembar penilaian akan menghasilkan data yang akan digunakan untuk menentukan kevalidan produk berupa bahan ajar dengan menggunakan model Problem Based Learning (PBL). Data penilaian kevalidan bahan ajar diperoleh dari dosen ahli bahasa, ahli materi dan ahli media, data lembar penilaian kevalidan bahan ajar diidentifikasi dengan langkah-langkah sebagai berikut:

1) Memberikan skor untuk setiap item dengan jawaban sangat baik (4), baik (3), tidak baik (2), dan sangat tidak baik (1).

2) Pemberian nilai validitas dengan rumus berikut:

$$
\mathrm{V}=\sum S /[\mathrm{n}(\mathrm{c}-1)]
$$

Azwar (2015:113)

\section{Keterangan:}

$\mathrm{S}=\mathrm{r}-\mathrm{lo}$

lo = Angka penilaian validitas yang terendah (dalam hal ini $=1)$

$\mathrm{c} \quad=$ Angka penilaian validitas yang tertinggi (dalam hal ini $=5$ )

$\mathrm{r} \quad=$ Angka yang diberikan oleh seorang penilai

3) Mencocokkan rata-rata validitas dengan kriteria kevalidan bahan ajar.

Tabel 1. Interpretasi Validitas Aiken's $V$

\begin{tabular}{|c|c|}
\hline Koefisien Korelasi & Interpretasi Validitas \\
\hline$>0,80$ & Tinggi \\
\hline $0,60 \leq V<0,80$ & Cukup Tinggi \\
\hline $0,40 \leq V<0,60$ & Cukup \\
\hline $0 \leq V<0,40$ & Buruk \\
\hline
\end{tabular}

Sumber: Febriandi (2019:152)

\section{b. Uji Kepraktisan Bahan Ajar}

Menurut Arifin (2012: 264) mengemukakan bahwa kepraktisan adalah syarat suatu tes standar. kepraktisan bahan ajar dengan menggunakan model Problem Based Learning (PBL) dapat dilihat dari hasil identifikasi angket kepraktisan siswa dan guru Hasil penilaian pada siswa dan guru pada lembar kepraktisan dicari dengan cara berikut:

1) Angket respon siswa diberikan skor untuk setiap item dengan jawaban "Ya" (1) dan "Tidak" (0). Sedangkan untuk angket respon guru diberikan skor sangat setuju (4), setuju (3), tidak setuju (2), sangat tidak setuju (1). 
2) Pemberian nilai kepraktisan dengan rumus berikut:

$$
\text { Tingkat Kepraktikalitas }=\frac{\text { Jumlah skor yang diperoleh }}{\text { jumlah skor total }} \times 100 \%
$$

Hidayat (2017:56)

3) Mencocokkan rata-rata kepraktisan dengan kriteria kepraktisan bahan ajar.

Tabel 2. Kriteria Kepraktisan Bahan Ajar

\begin{tabular}{|c|c|}
\hline Interval Rata-rata Skor & Klarifikasi \\
\hline $81 \%-100 \%$ & Sangat Praktis \\
\hline $61 \%-80 \%$ & Praktis \\
\hline $41 \%-60 \%$ & Cukup Praktis \\
\hline $21 \%-40 \%$ & Kurang Praktis \\
\hline $0 \%-20 \%$ & Tidak Praktis \\
\hline
\end{tabular}

Sumber : Riduan dalam Hidayat (2017:56)

\section{HASIL PENELITIAN DAN PEMBAHASAN}

Bahan Ajar Matematika berbasis Problem Based Learning untuk siswa kelas V Sekolah Dasar pada materi statistika yang telah disusun perlu dilakukan validasi sebelum uji cobakan ke lapangan. Bahan ajar yang telah selesai dirancang kemudian melakukan tahap validasi dengan memberikan lembar validasi kepada masing-masing ahli. Validasi ahli dilakukan untuk mendapatkan masukan dan saran sekaligus memberikan penilaian terhadap bahan ajar yang telah disusun dan dirancang dengan menggunakan model skala Likert yaitu skor 1 sampai dengan 4 dengan keterangan masing-masing menunjukkan penilaian yang sangat baik, baik, tidak baik, dan sangat tidak baik. Kriteria validasi bahan ajar ini teridiri dari 3 ahli validasi yaitu: validasi ahli bahasa, materi dan media.

Hasil penilaian dari ketiga ahli dianalisis dengan menggunakan formula Aiken's $V$ untuk mengetahui validitas bahan ajar Matematika berbasis Problem Based Learning untuk siswa kelas V Sekolah dasar yang telah dikembangkan.

\section{Ahli Bahasa}

Validator ahli bahasa memvalidasi komponen bahasa yang terdapat pada bahan ajar yang dihasilkan. Pernyataan yang terdapat di dalam angket validasi bahasa terdiri dari 14 pernyataan. Ahli bahasa memberikan penilaian terhadap 
bahan ajar Matematika berbasis Problem Based Learning untuk siswa kelas V Sekolah Dasar pada materi statistika dari penggunaan bahasa yang ada di dalam bahan ajar dan disesuaikan dengan kaidah yang benar dalam Bahasa Indonesia dan juga sesuai dengan keilmuan yang dimilikinya.

Selain memberikan penilaian terhadap bahan ajar Matematika berbasis Problem Based Learning untuk siswa kelas V Sekolah Dasar pada materi statistika, ahli juga memberikan saran dan masukan terhadap bahan ajar yang masih banyak kekeliruan dan kesalahan. Hasil dari penilaian ahli bahasa dianalisis dengan menggunakan formula Aiken's $V$ untuk mengetahui validitas bahan ajar Matematika berbasis Problem Based Learning untuk siswa kelas V SD pada materi statistika yang disusun dan dikembangkan. Adapun hasil validasi yang telah dianalisis dengan menggunakan formula Aiken's $V$ tersebut disajikan dalam bentuk Tabel 3 yang tersusun berdasarkan aspek yang dinilai.

Tabel 3. Hasil Analisis Validasi Ahli Bahasa menggunakan Aiken'V

\begin{tabular}{|c|c|c|c|c|}
\hline $\begin{array}{c}\text { Aspek } \\
\text { yang } \\
\text { dinilai }\end{array}$ & Indikator Penilaian & $\begin{array}{c}\text { Banyak } \\
\text { Butir }\end{array}$ & $\begin{array}{c}\text { Angka } \\
\text { Aiken's } \\
\boldsymbol{V}\end{array}$ & $\begin{array}{c}\text { Kriteria } \\
\text { Koofisiens } \\
\text { Aiken's } \boldsymbol{V}\end{array}$ \\
\hline \multirow{4}{*}{$\begin{array}{c}\text { Kelayakan } \\
\text { Bahasa }\end{array}$} & Lugas & 3 & 0,7 & Cukup Tinggi \\
\cline { 2 - 5 } & Komunikatif & 1 & 0.7 & Cukup Tinggi \\
\cline { 2 - 5 } & $\begin{array}{c}\text { Dialogis dan interaktif } \\
\text { perkesuaian dengan }\end{array}$ & 1 & 0,7 & Cukup Tinggi \\
\cline { 2 - 5 } & $\begin{array}{c}\text { Kesesuaian dengan kaidah } \\
\text { bahasa }\end{array}$ & 6 & 0,7 & Cukup Tinggi \\
\hline \multicolumn{2}{|c|}{ V rata-rata } & 0,7 & Cukup Tinggi \\
\hline
\end{tabular}

\section{Ahli Materi}

Lembar penilaian bahan ajar ahli materi berisi tentang penilaian terhadap cakupan materi yang ada di dalam bahan ajar Matematika berbasis Problem Based Learning. Pada lembar penilaian bahan ajar ahli materi terdapat 22 pernyataan. Ahli materi memberikan penilaian sesuai dengan keilmuan yang dimilikinya, selain memberikan penilaian ahli materi juga memberikan saran dan masukan terhadap bahan ajar Matematika berbasis Problem Based Learning untuk siswa kelas V SD pada materi statistika yang masih memiliki banyak kekeliruan dan kesalahan. 
Hasil dari penilaian ahli materi dianalisis dengan menggunakan formula Aiken's $V$ untuk mengetahui validitas bahan ajar Matematika berbasis Problem Based Learning untuk siswa kelas V SD pada materi statistika yang disusun dan dikembangkan mendapat respon yang baik dari validator ahli materi dilihat dari penilaian yang diberikan oleh ahli yang menunjukkan bahwa bahan ajar Matematika berbasis Problem Based Learning untuk siswa kelas V SD pada materi statistika valid dari segi materi sehingga bahan ajar ini bisa digunakan dalam proses pembelajaran. Adapun hasil validasi yang telah dianalisis dengan menggunakan formula Aiken's $V$ tersebut disajikan dalam bentuk Tabel 4 yang tersusun berdasarkan aspek yang dinilai.

Tabel 4 Hasil Analisis Validasi Ahli Materi menggunakan Aiken's V

\begin{tabular}{|c|c|c|c|c|}
\hline $\begin{array}{c}\text { Aspek yang } \\
\text { dinilai }\end{array}$ & Indikator Penilaian & $\begin{array}{c}\text { Banyak } \\
\text { Butir }\end{array}$ & $\begin{array}{l}\text { Angka } \\
\text { Aiken's } V\end{array}$ & $\begin{array}{c}\text { Kriteria Koefesien } \\
\text { Aiken's } V\end{array}$ \\
\hline \multirow{4}{*}{$\begin{array}{l}\text { Kelayakan } \\
\text { isi }\end{array}$} & $\begin{array}{l}\text { Kesesuaian materi } \\
\text { dengan KD }\end{array}$ & 3 & 0,8 & Tinggi \\
\hline & Keakuratan materi & 4 & 0,85 & Tinggi \\
\hline & Kemutakhiran materi & 2 & 1 & Tinggi \\
\hline & $\begin{array}{l}\text { Mendorong } \\
\text { keingintahuan }\end{array}$ & 2 & 0,85 & Tinggi \\
\hline \multirow{2}{*}{$\begin{array}{c}\text { Aspek } \\
\text { kelayakan }\end{array}$} & Teknik penyajian & 1 & 0,7 & Cukup Tinggi \\
\hline & Pendukung penyajian & 4 & 0,85 & Tinggi \\
\hline Penyajian & $\begin{array}{l}\text { Penyajian } \\
\text { pembelajaran }\end{array}$ & 1 & 0,7 & Cukup Tinggi \\
\hline \multirow{2}{*}{$\begin{array}{c}\text { Aspek } \\
\text { penilaian } \\
\text { Problem } \\
\text { Based } \\
\text { Learning }\end{array}$} & $\begin{array}{l}\text { Kebenaran isi atau } \\
\text { materi }\end{array}$ & 3 & 0,8 & Tinggi \\
\hline & $\begin{array}{l}\text { Keruntutan } \\
\text { sistematika materi }\end{array}$ & 2 & 0,85 & Tinggi \\
\hline \multicolumn{3}{|c|}{ V rata-rata } & 0,82 & Tinggi \\
\hline
\end{tabular}

\section{Ahli Media}

Lembar penilaian bahan ajar ahli media berisi tentang penilaian terhadap penyajian bahan ajar (struktur maupun format bahan ajar), pada lembar validasi media ini terdapat 17 pernyataan. Ahli media memberikan penilaian sesuai dengan keilmuan yang dimilikinya. Selain memberikan penilaian ahli media juga memberikan saran dan masukan terhadap bahan ajar Matematika berbasis 
Problem Based Learning untuk siswa kelas V SD pada materi statistika yang masih memiliki banyak kekeliruan dan kesalahan.

Hasil dari penilaian ahli media dianalisis dengan menggunakan formula Aiken's $V$ untuk mengetahui validitas bahan ajar Matematika berbasis Problem Based Learning untuk siswa kelas V SD pada materi statistika yang disusun dan dikembangkan. Adapun hasil validasi yang telah dianalisis dengan menggunakan formula Aiken's $V$ tersebut disajikan dalam bentuk Tabel 5 yang tersusun berdasarkan aspek yang dinilai.

Tabel 5 Hasil Analisis Validasi Ahli Media menggunakan Aiken's V

\begin{tabular}{|c|c|c|c|c|}
\hline $\begin{array}{c}\text { Aspek yang } \\
\text { dinilai }\end{array}$ & Indikator Penilaian & $\begin{array}{c}\text { Banyak } \\
\text { butir }\end{array}$ & $\begin{array}{c}\text { Angka } \\
\text { Aiken's } \\
\text { V }\end{array}$ & $\begin{array}{c}\text { Kriteria } \\
\text { Koofesien } \\
\text { Aiken's V }\end{array}$ \\
\hline \multirow{3}{*}{$\begin{array}{c}\text { Kelayakan } \\
\text { Kegrafika }\end{array}$} & Ukuran bahan ajar & 2 & 1 & Tinggi \\
\hline & $\begin{array}{l}\text { Desain Sampul bahan } \\
\text { ajar (cover) }\end{array}$ & 7 & 0,64 & $\begin{array}{l}\text { Cukup } \\
\text { Tinggi }\end{array}$ \\
\hline & Desain Isi bahan ajar & 18 & 0,7 & $\begin{array}{l}\text { Cukup } \\
\text { Tinggi }\end{array}$ \\
\hline \multicolumn{3}{|c|}{ V rata-rata } & 0,78 & Tinggi \\
\hline
\end{tabular}

\section{Penilaian Seluruh Validator}

Berdasarkan keseluruhan penilaian kevalidan bahan ajar yang diberikan oleh tiga ahli yaitu ahli bahasa, ahli materi dan ahli media terhadap bahan ajar yang sudah dijelaskan di atas menunjukan bahwa bahan ajar Matematika berbasis Problem Based Learning untuk kelas V SD pada materi statistika yang telah disusun dikembangkan dan dihasilkan memperoleh skor rata-rata 0,76 dan disesuaikan dengan tabel 4.7 interpretasi validitas Aiken's $V$ termasuk ke dalam kategori $0,60 \leq V<0,80$ dengan keterangan cukup tinggi atau dapat dikatakan valid. Sehingga dapat disimpulkan bahwa bahan ajar Matematika berbasis Problem Based Learning untuk siswa kelas V SD pada materi statistika dapat dikategorikan valid untuk digunakan dalam proses pembelajaran. Rekapitulasi hasil keseluruhan penilaian kevalidan dari ketiga ahli dapat dilihat pada Tabel 6 . 
Pengembangan Bahan Ajar.... (Fida Lestari, Asep Sukenda Egok, Riduan Febriandi)

Tabel 6 Hasil Penilaian Seluruh Validator

\begin{tabular}{|c|c|c|c|c|}
\hline \multirow{2}{*}{ No } & \multirow{2}{*}{ Nama Ahli } & \multicolumn{3}{|c|}{ Skor yang diperoleh } \\
\cline { 3 - 5 } & & Bahasa & Materi & Media \\
\hline 1 & Dr. Rusmana Dewi, M. Pd & 0,7 & - & - \\
\hline 2 & Maria Luthfiana, M. Pd & - & 0,82 & - \\
\hline & Dr. Dodik Mulyono, M. Pd & - & - & 0,78 \\
\hline \multicolumn{3}{|c|}{0,82} & 0,78 \\
\hline \multicolumn{2}{|c|}{ Jumlah } & 0,7 & \multicolumn{3}{|c|}{0,76} \\
\hline
\end{tabular}

Analisis kevalidan berdasarkan data pengisian angket oleh tiga ahli menunjukan bahwa draf 1 bahan Matematika berbasis Problem Based Learning untuk siswa kelas V SD pada materi statistika yang telah diperbaiki berdasarkan perhitungan data pengisian angket dengan skor rata-rata 0,76 dan disesuaikan dengan tabel 4.7 interpretasi validitas Aiken's $V$ termasuk ke dalam kategori 0,60 $\leq V<0,80$ dengan keterangan cukup tinggi atau dapat dikatakan valid. Dari hasil perhitungan menggunakan Aiken's $V$ dapat disimpulkan bahwa hasil analisis validasi seluruh ahli menyatakan bahan ajar Matematika berbasis Problem Based Learning untuk siswa kelas V SD pada materi statistika yang disusun dan dikembangkan valid untuk digunakan dalam proses pembelajaran.

Final produk bahan ajar Matematika berbasis Problem Based Learning disajikan dalam Tabel 7 berikut ini:

Tabel 7. Format Penyusunan Bahan Ajar

\begin{tabular}{|c|c|c|}
\hline No & $\begin{array}{c}\text { Unsur Bahan } \\
\text { Ajar }\end{array}$ & Deskripsi Bahan Ajar \\
\hline 1 & Cover depan & $\begin{array}{l}\text { Halaman depan berisi judul bahan ajar dan identitas } \\
\text { pemilik bahan ajar }\end{array}$ \\
\hline 2 & Kata pengantar & Sebagai pengantar dalampenulisan bahan ajar \\
\hline 3 & Daftar isi & $\begin{array}{l}\text { Petunjuk agar mempermudah menuju kehalaman yang } \\
\text { ingin dicari }\end{array}$ \\
\hline 4 & Petunjuk umum & $\begin{array}{l}\text { Berisi petunjuk bagi siswa dalam penggunaan bahan } \\
\text { ajar }\end{array}$ \\
\hline 5 & $\begin{array}{l}\text { KI, KD, dan } \\
\text { Indikator }\end{array}$ & $\begin{array}{l}\text { Muatan materi dalam bahan ajar disusun berdasarkan } \\
\text { tujuan pembelajaran }\end{array}$ \\
\hline 6 & Peta konsep & $\begin{array}{l}\text { Berupa peta konsep materi yang tertuang di dalam } \\
\text { bahan ajar }\end{array}$ \\
\hline
\end{tabular}




\begin{tabular}{|c|l|l|}
\hline No & $\begin{array}{c}\text { Unsur Bahan } \\
\text { Ajar }\end{array}$ & \multicolumn{1}{c|}{ Deskripsi Bahan Ajar } \\
\hline 7 & Materi & $\begin{array}{l}\text { Materi statistika terdiri dari 8 materi yang meliputi: } \\
\text { mengumpulkan data, menyajikan data, membuat tabel } \\
\text { frekuensi, menyajikan data dalam bentuk diagram, } \\
\text { diagram gambar, diagram grafis, diagram lingkaran, } \\
\text { menafsirkan dan membaca sajian data. }\end{array}$ \\
\hline 8 & $\begin{array}{l}\text { Problem Based } \\
\text { Learning }\end{array}$ & $\begin{array}{l}\text { Pembelajaran diawali dengan memberikan sebuah } \\
\text { permasalahan kepada siswa sesuai materi yang akan } \\
\text { diajarkan dan pemecahan masalah dilakukan secara } \\
\text { berkelompok }\end{array}$ \\
\hline 9 & Tugas individu & $\begin{array}{l}\text { Tugas diakhir pembelajaran diberikan untuk melihat } \\
\text { kemampuan peserta didik dalam menguasai materi. }\end{array}$ \\
\hline 10 & Daftar pustaka & Ditulis sebagai referensi dalam penulisan bahan ajar \\
\hline 11 & Cover belakang & Sebagai sampul belakang \\
\hline
\end{tabular}

Desain pengembangan produk awal setelah dilakukan validasi ahli dengan merevisi produk yang dirancang, diperoleh sebuah produk final berupa bahan ajar Matematika berbasis Problem Based Learning untuk siswa kelas V SD pada materi statistika.

\section{PEMBAHASAN}

Berdasarkan penjelasan hasil penelitian di atas, diperoleh produk penelitian berupa bahan ajar Matematika berbasis Problem Based Learning yang membahas materi statistika. Adapun tahapan proses desain pengembangan bahan ajar Matematika berbasis Problem Based Learning sebagai berikut:

\section{Tahap Pendefinisian (Define)}

Tahap Pendefinisian (Define) merupakan tahap analisis, ada beberapa langkah analisis yang dilakukan oleh peneliti pada tahap ini, diantaranya: analisis awal, analisis siswa, analisis tugas, analisis konsep, dan analisis tujuan pembelajaran. Maka dari itu, solusi yang bisa digunakan adalah penggunaan bahan ajar Matematika berbasis Problem Based Learning dikarenakan bahan ajar ini bisa menarik perhatian siswa dengan tampilan yang tidak membosankan dan membantu siswa agar mudah memahami materi pembelajaran. Bahan ajar ini juga didukung dengan berbasis Problem Based Learning yang dapat melibatkan siswa secara aktif, kreatif, dan mempunyai keterampilan dalam memecahkan permasalahan yang terkait dengan materi statistika. 


\section{Tahap Perancangan (Design)}

Tahap perancangan merupakan tahap yang kedua, terdiri dari 4 langkah yaitu penyusunan tes acuan patokan, pemilihan media, pemilihan format, dan desain awal. Pertama, dimulai dari tahap penyusunan tes acuan patokan, tahap ini peneliti membuat soal-soal untuk digunakan dalam bahan ajar yang berkaitan dengan materi statistika. Dilanjutkan dengan tahap yang kedua yaitu pemilihan media, pada tahap ini peneliti memilih bahan ajar sebagai media yang digunakan untuk mempermudah dalam penyampaian materi pembelajaran kepada siswa. Kemudian penulisan bahan ajar ini menggunakan format yang berbasis Problem Based Learning serta materi yang ada pada bahan ajar sesuai dengan kompetensi dasar kurikulum 2013 yaitu materi statistika sehingga tersusunlah desain awal berupa bahan ajar draf 1 .

\section{Tahap Pengembangan (Develop)}

Pelaksanaan pada tahap pengembangan ini ialah melakukan validasi bahan ajar oleh para ahli diikuti dengan revisi dan uji coba one to one, small group, dan uji kepraktisan guru untuk mengetahui kepraktisan dari bahan ajar yang dikembangkan. Adapun pembahasan proses validitas dan praktikalitas sebagai berikut:

\section{a. Validitas Bahan Ajar Matematika Berbasis Problem Based Learning}

Bahan ajar Matematika yang telah dikembangkan telah dianalisis oleh 3 ahli dibidangnya, diantaranya ahli bahasa, ahli materi, dan ahli media. Bahan ajar Matematika dikembangkan untuk memenuhi kebutuhan siswa dalam mempelajari materi yang dianggap sulit dipahami dan membosankan. Sebagai pengganti peran guru ketika siswa belajar secara mandiri, bahan ajar Matematika yang dikembangkan harus valid sebelum digunakan siswa belajar. Bahan ajar Matematika dirancang berdasarkan format penyusunan bahan ajar, diantaranya cover depan, halaman keterangan bahan ajar, kata pengantar, daftar isi, petunjuk umum, KI, KD, indikator, tujuan pembelajaran, peta konsep, materi, halaman latihan, halaman tugas individu, daftar pustaka, dan cover belakang.

Berdasarkan hasil analisis penilaian kevalidan bahan ajar oleh para ahli bahan ajar Matematika berbasis Problem Based Learning ini memperoleh respon 
sangat baik dilihat dari hasil penilaian validator terhadap bahan ajar Matematika berbasis Problem Based Learning yang dikategorikan cukup tinggi atau sama dengan valid, serta layak untuk diuji cobakan dengan beberapa perbaikan sesuai masukan dan saran dari ketiga ahli validator.

\section{b. Praktikalitas Bahan Ajar Matematika berbasis Problem Based Learning}

Setelah bahan ajar direvisi tahap selanjutnya ialah diuji cobakan pada guru, one to one yang terdiri dari 3 orang siswa, dan kelompok kecil (small group) yang terdiri dari 6 orang siswa kelas Vb SD Negeri 37 Lubuklinggau untuk mengetahui kepraktisan bahan ajar Matematika yang dikembangkan. Agar mengetahui kepraktisan bahan ajar Matematika yang dikembangkan tersebut, setelah siswa selesai melakukan pembelajaran dengan menggunakan bahan ajar Matematika siswa memberikan tanggapan dengan mengisi lembar respon peserta didik terhadap penyajian bahan ajar Matematika berbasis Problem Based Learning. Dalam pembuatan produk bahan ajar Matematika Problem Based Learning ini, siswa kelas V SD Negeri 37 Lubuklinggau yang menjadi responden untuk memberikan tanggapan terhadap bahan ajar yang telah dipelajari selama penelitian dilakukan.

Aspek-aspek dalam angket respon peserta didik mengacu kepada perhatian siswa pada bahan ajar saat pembelajaran berlangsung, ketertarikan siswa terhadap penyajian bahan ajar Matematika maupun untuk belajar lebih lanjut, keyakinan dalam motivasi dalam belajar dengan model pembelajaran Problem Based Learning, dan aspek kepuasan siswa dalam mengekspresikan hasil belajarnya dalam menggunakan bahan ajar Matematika yang dikembangkan.

\section{SIMPULAN}

Penelitian ini menghasilkan sebuah produk baru, yaitu bahan ajar Matematika berbasis Problem Based Learning untuk siswa kelas V SD pada materi statistika. Hasil penelitian disimpulkan bahwa bahan ajar Matematika berbasis Problem Based Learning untuk siswa kelas V SD pada materi statistika yang dikembangkan valid dan praktis serta layak digunakan untuk guru dalam mengajar dan untuk peserta didik dalam belajar. 


\section{DAFTAR PUSTAKA}

Arifin, Z. (2012). Evaluasi Pembelajaran. Bandung: PT Remaja Rosdakarya.

Arikunto, S. (2010). Prosedur Penelitian Suatu Pendekatan Praktik. Jakarta: Rineka Cipta.

Azwar, S. (2015). Reliabilitas dan Validitas. Yogyakarta: Pustaka Pelajar.

Febriandi, R. (2019). Validitas Lembar Kerja Siswa Matematika Dengan Pendekatan Saintifik Berbasis Outdoor Untuk Siswa Kelas IV SD Pada Materi Bangun Datar. Jurnal Pembelajaran dan Pengajaran Pendidikan Dasar. 2 (2) 148-158.

Febriandi, R. (2020). Upaya meningkatkan hasil belajar matematika Melalui pendekatan scientific dengan pembelajaran Cooperative learning pada siswa kelas IV Sekolah Dasar. Journal of Elementery School. 3 (1) 29-37.

Hasanah, A. (2012). Pengembangan Profesi Guru. Bandung: CV Pustaka Setia.

Hidayat, A dan Irawan, I. (2017). Pengembangan LKS Berbasis RME dengan Pendekatan Problem Solving untuk Memfasilitasi Kemampuan Pemecahan Masalah Matematis SMA. Universitas Pahlawan Tuanku Tambusai. Jurnal Pendidikan Matematika. Vol.1, No.2, pp, 51-63.

Kharisma \& Asman. (2018). Pengembangan Bahan Ajar Matematika Berbasis Masalah Berorientasi pada Kemampuan Pemecahan Masalah Matematis dan Prestasi Belajar Matematika. Indonesian Journal of Mathematics Education. $1(1), 35-47$

Mahmud. (2011). Metode Penelitian Pendidikan. Bandung: Pustaka Setia.

Nurhidayati, dkk. (2017). Pengembangan Bahan Ajar Matematika Berbasis Masalah Untuk Memfasilitasi Pencapaian Kemampuan Penalaran Pada Pokok Bahasan Perbandingan Kelas VII MTSN Model Makassar. Jurnal Matematika dan Pembelajaran, 5 (2), 238-240.

Sugiyono. (2010). Metode Penelitian Pendidikan. (Pendekatan Kuantitatif, Kualitatif, dan $R \& D$ ). Bandung: Alfabeta.

Sugiyono. (2014). Statistika untuk Penelitian. Bandung: Alfabeta.

Sugiyono. (2015). Metode Penelitian Pendidikan. (Pendekatan Kuantitatif, Kualitatif, dan $R \& D$ ): Bandung: Alfabeta.

Sunhaji. (2014). Konsep Manajemen Kelas dan Implikasinya dalam Pembelajaran. Jurnal Kependidikan. II (2) 32-33.

Trianto. (2010). Mengembangkan Model Pembelajaran Tematik. Jakarta: PT Prestasi Pustaka. 